\title{
RESPONSE OF COMMON BEAN (Phaseolus vulgaris L.) TO ORGANIC AND BIO-FERTILIZERS UNDER DIFFERENT LEVELS OF NITROGEN MINERAL FERTILIZER. \\ Abd El-Hady, M.A. ${ }^{1}$ and E.I. Mohamed ${ }^{2}$ \\ Horticulture Research Institute, Agriculture Research \\ Center, Giza, Egypt. ${ }^{1}$ \\ Soil,Water\&Environment Research Institute, Agriculture \\ Research Center, Giza, Egypt. ${ }^{2}$
}

\begin{abstract}
Two field experiments in randomized complete block design with three replicates were carried out at Shandweel Agriculture Research Station, during 2013 and 2014 seasons. The objective of the the present study is to evaluate the application of organic fertilizer (FYM), biofertilizers (Microbien), humic acid and fulvic acid as substitutions of all or part of the nitrogen chemical fertilizer in fertilizing common bean variety Paulista. The obtained results indicated that any treatemnt of adding FYM, microbien and humic and fulvic acids with the recommended dose of nitrogen increased values of plant height, fresh root weight at 50 and 70 days from planting, nitrogen content fresh pods (\%), leaf area and number of pods/pant more than vaules the $\mathrm{N}$ rocommended dose (RD) only, and then with $3 / 4 \mathrm{~N} \mathrm{RD}$ and $1 / 2 \mathrm{~N} R D$, especially with adding humic and fulvic acids. Adding FYM, microbien and humic and fulvic acids with the recommended dose of nitrogen increased pod length, fresh pod yield (ton/fed) and exportable fresh pods yield (ton/fed) more than the $\mathrm{N}$ values rocommended dose (RD), and then with $3 / 4 \mathrm{~N} \mathrm{RD}$ and $1 / 2 \mathrm{~N} \mathrm{RD}$, especially with adding FYM. Adding FYM was effective on nitrogen content in leaves (\%) at the high levels of nitrogen (rocommended dose (RD) and $3 / 4 \mathrm{~N} \mathrm{RD}$ ), while, the effect of adding humic and fulvic acids were realized at the level of $1 / 2$ recommended dose of nitrogen fertilizer. The highest fresh pods yield, i.e., (3.985 and 3.961 ton/fed) were recorded by the combination between the recommended dose of chemical nitrogen plus the farm yard manure in the first and second season, respectively. No significant effect between 3/4 RD $(\mathrm{N})+\mathrm{FYM}, 3 / 4 \mathrm{RD}(\mathrm{N})+$ Microbien and 3/4 RD $(\mathrm{N})+$ humic and fulvic acids compared with the recommended dose of chemical nitrogen of the most studied traits. It is clear that the application of organic and biofertilizer with $3 / 4$ chemical fertilizer not only improve crop productivity but also decrease of mineral frtilizer and reduce environmental hazards.
\end{abstract}

Keywords: Common bean, nitrogen fertilization, FYM, microbien, humic and fulvic acids.

\section{INTRODUCTION}

Common bean (Phaseolus vulgaris L.) is economically one of the major vegetable crops in Egypt for local consumption as well as for the exportation. The significant role of chemical fertilizers in increasing crop plants production is fully recognized. However, in the recent years, many constraints have been raised due to their adverse impacts on the public health, environment and national income according to their high prices. To confront this problem, it was necessary to develop alternative methods of supplying nutrients to the growing plant. The use of natural organic manure is recommended by 
farmers and investigators to substitute all or part of the chemical fertilizers as it improves physical and chemical properties of soil and it is the way to achieve minimum pollution effects and reduce agriculture cost. Biofertilizers mainly comprise nitrogen fixer, phosphate dissolvers or vesicular arbuscular mycorrhizae fungi (VAM) and silicate bacteria. Moreover, biofertilizers are used in biological control of soil-born diseases and stimulate plant growth by producing growth regulators (El-Akabawy, 2000; De Silva and Cook, 2003 and Wu et al., 2005). It is considered a good source of plant nutrients and has a positive effect for improving of the soil physical structure (El-Akabawy, 2000 and Shen and Shen, 2001). Many investigators studied the effect of organic fertilizers and biofertilizers on both crop production and improvement of phisical and chemical properties of soil. Mel'nikova et al., (2002) studied the effects of bacteria belonging to the genera Azotobacter and Bacillus in a mixed culture with Bradyrhizobium japonicum strains on the formation and function of the legume-rhizobium symbiosis for soybean plants. The data show that the bacterial compositions $B$. japonicum $634 \mathrm{~b}+B$. subtilis $5, B$. japonicum $634 \mathrm{~b}+A$. chroococcum 20 , and $B$. japonicum $10 \mathrm{k}+A$. vinelandii56 with a cell ratio of $1: 0.1$ increased the number and weight of root nodules as well as the height and weight of the aboveground plant parts in almost cases by $22-105 \%$ compared with the control treatments. These binary microbial cultures may be used for the development of combined bacterial preparations for soybean. Abraham and Lal (2003) studied the effects of NPK fertilizer (100\% and $33 \%$ of the recommended Dose), organic manures (farm compost + vermicompost and farm compost + poultry manure) and biofertilizers (phosphate solubilizing bacteria (PSB) + Rhizobium/Azospirillum and PSB +2 foliar applications of $33 \%$ cow's urine) on the productivity of the soyabean-mustard-fodder cowpea cropping system. Farm compost + poultry manure or vermincompost in combination with inorganic fertilizers showed synergistic effects on the growth and yield of the crops. The values obtained for most of the parameters with $100 \%$ recommended fertilizer dose were higher than those with lower dose of fertilizers, but the latter were statistically at par with the former. PSB + cow's urine recorded higher values of dry matter accumulation than dual inoculation of PSB and Rhizobium in fodder cowpea. The percentage of organic carbon and available nutrient status of $\mathrm{P}_{2} \mathrm{O}_{5}$ and $\mathrm{K}_{2} \mathrm{O}$ in the soil also increased due to the integration of organic and inorganic sources of nutrients. Araújo (2007) studied the effect of composted textile sludge on growth, nodulation and nitrogen fixation of cowpea was evaluated in a greenhouse experiment. The compost was incorporated into soil at $0,9.5,19$ and $38 \mathrm{t} \mathrm{ha}^{-1}$ (bases upon the $\mathrm{N}$ requirement of the crops, i.e., $0,50,100$ and $200 \mathrm{~kg}$ available $\mathrm{N} \mathrm{ha}^{-1}$ ). Composted textile sludge did not show negative effects on nodule number and weight, Nitrogen accumulation in dry matter of shoots in cowpea was higher than other treatments with application of $19 \mathrm{tha}^{-1}$ of compost. Composting can be an alternate technology for the management of solid textile mill sludge. This study verifies that the composted textile sludge was not harmful to growth, nodulation and nitrogen fixation of cowpea. Khalilzadeh, et al., (2012) study the effect of ten treatments (Urea, Nitroxin, Amino acid, Green hum, Biocrop L-45, Nutriman N24 and Mas Raiz, cattle 
manure, water and control) foliar spraying on root and vegetative growth of mung bean (Vigna radiata L.) in a greenhouse condition. Results showed that all traits were significantly affected by treatments except the number of second roots. Foliar application of urea and organic manure substantially improved the plant height, leaf area, shoot and root dry weights, root and shoot length, volume and number of roots. Similarly shoot and leave number and nodules root were also improved by the foliar spraying of green hum and amino acid, respectively. While the lowest nodules root was observed in plants treated by nutriman N24 and urea. This improved growth of mainly due to nutrient availability in bio-organic fertilizer and uptake by plants.

Humic acid increases the permeability of plant membranes and enhance the uptake of nutrients. Humic acid is also improves soil nitrogen uptake and encourage the uptake of potassium, calcium, magnesium and phosphorus, making these more mobile and available to plant root system. Additionally, the influence of humic material on plant growth, have been investigated on numerous studies have shown that humic substances enhance root, leaf and shoot growth but also stimulate the germination of various crop species (Piccolo et al., 1997, Singer et al., 1998 and Pascual et al., 1999). Using Humic and fulvic acids are considered to be compounds increasing permeability of cellular membranes in plants to vitamins within the cell (Kaya et al., 2005).

Common bean crop normally fertilized with chemical fertilizers, which may have hazardous effect on soil environment and crop quality. Therefore, the present study aimed to evaluate the application of organic matter, biofertilizers and humic and fulvic acid as substitution of all or a part of chemical fertilizer needed for fertilizing common bean plants.

\section{MATERIALS AND METHODS}

The present study was carried out at Shandweel Agric Res. Stat., Agric. Res. Center, Ministry of Agric., Egypt during 2013 and 2014 seasons. The objective of the present study is to evaluate the application of organic fertilizer (FYM), biofertilizers and humic and fulvic acid as substitution of all or part of the nitrogen fertilizers in fertilizing common bean variety Paulista.

The experiments were designed in randomized complete block design with three replicates. Soil physical and chemical analyses of the experimental sites for the two seasons are presented in Table 1 and were determined as Jackson (1967).

Table 1. Soil characterization for the experimental sites.

\begin{tabular}{|l|c|c|c|c|c|c|c|}
\hline Seasons & Texture & $\mathbf{C a C O}_{3} \%$ & Soil pH & $\mathbf{O} . \mathbf{M} \%$ & $\mathbf{A}$ & $\mathbf{P}$ & $\mathbf{K}$ \\
\hline 2013 & $\begin{array}{c}\text { Sandy } \\
\text { loom }\end{array}$ & 7.50 & 7.9 & 0.6 & 18 & 25 & 120 \\
\hline 2014 & $\begin{array}{c}\text { Sandy } \\
\text { loom }\end{array}$ & 7.55 & 7.7 & 0.8 & 21 & 27 & 130 \\
\hline
\end{tabular}


Twelve treatments of three levels of chemical of nitrogen fertilizer combined with farm yard manure or biofertilized as well as himic and fulvic acids beside the control (untreated) were used as follows:

1. Control (untreated).

2. Recommended dose of nitrogen ( $33.5 \mathrm{~kg} \mathrm{~N} / \mathrm{fed}$ ) mineral fertilizer (RD).

3. Recommended dose of nitrogen $+F Y M\left(20 \mathrm{~m}^{3} / \mathrm{fed}\right.$. $)$.

4. Recommended dose of nitrogen + biofertilizer (Microbien).

5. Recommended dose of nitrogen + humic acid (humate potassium) and fulvic acid.

6. $3 / 4$ Recommended dose of nitrogen $(25.125 \mathrm{~kg} \mathrm{~N} / \mathrm{fed})$.

7. $3 / 4$ Recommended dose of nitrogen + FYM $\left(20 \mathrm{~m}^{3} / \mathrm{fed}\right.$.).

8. $3 / 4$ Recommended dose of nitrogen + biofertilizer (Microbien).

9. $3 / 4$ Recommended dose of nitrogen + humic acid (humate potassium) and fulvic acid.

10. $1 / 2$ Recommended dose of nitrogen $(16.75 \mathrm{~kg} \mathrm{~N} / \mathrm{fed})$.

11. $1 / 2$ Recommended dose of nitrogen $+F Y M\left(20 \mathrm{~m}^{3} / \mathrm{fed}\right.$. $)$.

12. $1 / 2$ Recommended dose of nitrogen + biofertilizer (Microbien).

13. $1 / 2$ Recommended dose of nitrogen + humic acid (humate potassium) and fulvic acid.

The area of experimental plot was $10.5 \mathrm{~m}^{2}$ ( 5 ridges $\times 0.6 \mathrm{~m}$ width $\times 3.5$ $\mathrm{m}$ length). Common beans seeds (cv. Paulista) were sown at $1^{\text {st }}$ September in 2013 and 2014 seasons, in hills $10 \mathrm{~cm}$ apart on one side of ridges and two seeds per hill.

The recommended doses of NPK were added as follows: $\mathrm{N}$-fertilizer was added at 60,45 and $30 \mathrm{~kg} \mathrm{~N} / \mathrm{feddan}$ and was applied as Ammonium nitrate $(33.5 \% \mathrm{~N})$ in one dose before the first irrigation. Phosphorus fertilizer was added as superphosphate $\left(15.5 \% \mathrm{P}_{2} \mathrm{O}_{5}\right)$ at the rate of $22.5 \mathrm{~kg} \mathrm{P}_{2} \mathrm{O}_{5} / \mathrm{feddan}$ before sowing, and potassium as potassium sulfate $\mathrm{K}_{2} \mathrm{SO}_{4}\left(48 \% \mathrm{~K}_{2} \mathrm{O}\right)$ was added to the soil before the first irrigation at the rate of $24 \mathrm{~kg} \mathrm{~K} / \mathrm{feddan}$.

Farm Yard Manure (FYM) was added at the rate of $20 \mathrm{~m}^{3} / \mathrm{feddan}$ at land preparing. Chemical analysis of FYM was presented in Table (2).

Table (2): Chemical analysis of Farm Yard Manure (FYM) used in the experiments.

\begin{tabular}{|r|c|c|c|c|c|c|c|}
\hline $\begin{array}{r}\text { Chemica } \\
\text { composition }\end{array}$ & $\begin{array}{c}\mathbf{p H} \\
\mathbf{1 : 2 . 5}\end{array}$ & $\mathbf{O} . \mathbf{M} \%$ & $\mathbf{C} \%$ & $\mathbf{N} \%$ & $\begin{array}{c}\text { C:N } \\
\text { Ratio }\end{array}$ & $\mathbf{P} \%$ & $\mathbf{K} \%$ \\
\hline Prganic matter & 7.7 & 21.04 & 12.64 & 0.52 & $20.69: 1$ & 0.26 & 1.13 \\
\hline FYM & 7.5 &
\end{tabular}

Before planting, common bean seeds were inoculated with biofertilizer, using gum arabic solution as a sticking agent. Biofertilizers of Microbien (asymbiosis nitrogen-fixing bacteria and phosphate solubilizing microorganism) was obtained from Agric. Res. Center, Giza, Egypt. Humic acid has the average chemical formula $\mathrm{C}_{187} \mathrm{H}_{186} \mathrm{O}_{89} \mathrm{~N}_{9} \mathrm{~S}_{1}$. Fulvic acid has the average chemical formula $\mathrm{C}_{135} \mathrm{H}_{182} \mathrm{O}_{95} \mathrm{~N}_{5} \mathrm{~S}_{2}$. Plants were sprayed twice with freshly prepared solution of humic and fulvic acids at the rate of $4 \mathrm{~cm}^{3} / \mathrm{L} \mathrm{H} \mathrm{H}_{2} \mathrm{O}$ at 30 and 45 days after sowing. 
The following characters were studied:

1- Plant height $(\mathrm{cm})$ : measured prior to harvesting for 10 plants from cotyledonary to the terminal.

2- Pod length $(\mathrm{cm})$ : measured as an average of 10 pods per plant.

3- Pod diameter $(\mathrm{cm})$ : measured as an average of 10 pods per plant.

4- Fresh root weight (g): it was determined, 50 and 70 days from planting.

5- Leaf area $\left(\mathrm{dm}^{2}\right)$, it was determined by using C1-202 AREA METER/CID, INC.

6- Nitrogrn content percentage: it was determined in leaves and fresh pods using the micro-kjeldahl method as outlined the total nitrogen (according to A.O.A.C. 1984).

7- Number of pods per plant: recorded as an average of 10 plants that were randomly taken from each plot.

8- Fresh pod yield (ton/fed): total fresh pod yield per feddan (ton/fed.).

9- Exportable fresh pods yield (ton/fed).

The obtained data were statistically analysis by Gomez and Gomez (1984) and the treatments means were compared using different litters according to Duncan's multiple range test (Duncan, 1955).

\section{RESULTS AND DISCUSSION}

\section{Plant height (cm):}

Data presented in Table (3) clearly show that applying mineral fertilizer nitrogen recommended dose or its parts combined with organic (FYM), biofertilizers (Micribein) or humic and fulvic acids significantly increased plant height as compared to untreated treatment (control), in the two seasons of study. Applying the recommended dose of mineral fertilizer nitrogen plus humic and fulvic acids gave the highest values of this trait, i.e., 29.37 and $31.77 \mathrm{~cm}$, in the first and second seasons, respectively. However, the combination between the recommended dose of nitrogen and farm yard manure, microbien or humic and fulvic acids significantly increased plant height as compared to the recommended dose of nitrogen alone. The same trend was also observed under the parts of recommended dose of nitrogen fertilizer. Moreover, no significant defers 3/4 RD (N) + FYM, 3/4 RD (N) + Microbien or $3 / 4 \mathrm{RD}(\mathrm{N})+$ humic and fulvic acids compared with the recommended dose of chemical nitrogen in plant height. These results were true in the two seasons under study (2013 and 2014). These results may be due to the effect of farm yard manure, microbien and humic and fulvic acids in fixing atmosphric nitrogen and release phytohormones which encourage plant cell division (DeSilva and Cook, 2003 and Wu et al., 2005). Also, farm yard manure or humic and fulvic acids for play an important in improving the chemical and physical properties of soil, which positing reflect on plant growth. These results take the same trend with those found by El-Akabawy (2000) and Shen and Shen (2001).

Pod length and diameter:

Results illustrated in Table (3) indicate that values of pod length in all treatments of study were higher than those obtained by untreated treatment 
(control). The same trend was obtained for pod diameter. The results also show that there were significant increases pod length by adding $3 / 4 R D(N)+$ FYM, $3 / 4 R D(N)$ + Microbien or $3 / 4 R D(N)$ + humic and fulvic acids comparison with the recommended dose of nitrogen fertilizer. Meanwhile, the highest in values of pod length and diameter were produced by applying the recommended dose of nitrogen fertilizer plus spraying humic and fulvic acids, and the same trend was also found at the levels of parts of the recommended dose of nitrogen fertilizer $(3 / 4$ and $1 / 2 \mathrm{~N} R D)$. These results are true in the two experimental seasons (2013 and 2014). These results may be attributed to the beneficial effect of organic matter on the availability of macro and micro nutrients, which positively reflected on pod length and diameter parameters. These results are in agreement with those reported by El-Akabawy (2000) and Shen and Shen (2001).

Table (3): Effect of nitrogen fertilizers, organic (FYM), biofertilizer (Microbien) and humic and fulvic acids on pod length, pod diameter and plant height of common bean in 2013 and 2014 seasons.

\begin{tabular}{|c|c|c|c|c|c|c|}
\hline \multirow{2}{*}{ Treatments } & \multicolumn{2}{|c|}{ Plant height $(\mathrm{cm})$} & \multicolumn{2}{|c|}{ Pod length (cm) } & \multicolumn{2}{|c|}{$\begin{array}{l}\text { Pod diameter } \\
\text { (cm) }\end{array}$} \\
\hline & $\begin{array}{c}2013 \\
\text { season }\end{array}$ & $\begin{array}{c}2014 \\
\text { season }\end{array}$ & $\begin{array}{c}2013 \\
\text { season }\end{array}$ & $\begin{array}{c}2014 \\
\text { season }\end{array}$ & $\begin{array}{c}2013 \\
\text { season }\end{array}$ & $\begin{array}{c}2014 \\
\text { season }\end{array}$ \\
\hline Control (untreated) & $18.00 f$ & $17.20 f$ & $10.67 e$ & $10.97 e$ & $0.66 \mathrm{~b}$ & $0.64 b$ \\
\hline N Recommended Dose (RD) & & $28.97 b$ & $12.97 \mathrm{~cd}$ & 13.09bcd & & $0.81 \mathrm{a}$ \\
\hline $\mathrm{RD}(\mathrm{N})+(\mathrm{FYM})$ & 29.1 & $31.90 \mathrm{a}$ & $14.03 a$ & $14.18 a$ & $0.82 a$ & $.83 a$ \\
\hline$+($ Microbien $)$ & & & & & & $32 a$ \\
\hline RD (N) + (Humic\&Fulvic) & & $77 a$ & $3 a b$ & $14.07 a$ & $32 a$ & $84 a$ \\
\hline 3/4 N Recommended Dose (RD) & & & & $12.80 \mathrm{~cd}$ & $8 \mathrm{Ba}$ & $0.79 a$ \\
\hline $3 / 4 \mathrm{RD}(\mathrm{N})+(\mathrm{FYM})$ & $27.71 \mathrm{~b}$ & $28.87 \mathrm{~b}$ & $13.47 a b c$ & 13.67ab & $0.81 \mathrm{a}$ & $0.82 a$ \\
\hline J) + (Microbien $)$ & $26.90 b c$ & $28.20 \mathrm{~b}$ & $13.93 a$ & $13.95 a$ & $0.81 \mathrm{a}$ & $0.81 \mathrm{a}$ \\
\hline (N) + (Humic\&Fulvic) & $27.03 b c$ & & & & & $0.83 a$ \\
\hline 1/2 N Recommended Dose (RD) & & & & & $0.77 a$ & $0.77 a$ \\
\hline $1 / 2 \mathrm{RD}(\mathrm{N})+(\mathrm{FYM})$ & $25.80 \mathrm{~cd}$ & 26.07cd & $12.95 \mathrm{~cd}$ & $13.10 \mathrm{bcd}$ & $0.79 a$ & $0.79 a$ \\
\hline $1 / 2 \mathrm{RD}(\mathrm{N})+($ Microbien) & $25.07 d$ & $25.23 d$ & $12.53 d$ & $12.73 \mathrm{~cd}$ & $0.78 \mathrm{a}$ & $0.79 a$ \\
\hline $1 / 2$ RD $(\mathrm{N})+($ Humic\&Fulvic) & $26.47 \mathrm{bc}$ & $26.83 c$ & $13.07 \mathrm{~cd}$ & 13.07bcd & $0.80 a$ & $0.80 a$ \\
\hline
\end{tabular}

Mean values among variants were compared by using different litters according to Duncan's multiple range test.

\section{Fresh root weight at $\mathbf{5 0}$ and $\mathbf{7 0}$ days:}

The effect of chemical nitrogen fertilizer, organic, biofertilizer and humic and fulvic acids on fresh root weight at 50 and 70 days from palnting are presented in table (4). Data indicated that all studied treatments had significant effect cpmpared with the untreated one, in the two seasons of study. Applying the recommended dose of nitrogen plus humic and fulvic acids produced the highest values for fresh root weight at 50 and 70 days from planting, in the two seasons under study. Applying farm yard manure, microbien or humic and fulvic acids with the recommended dose of nitrogen fertilizer significantly increased values of these characters as compared to the recommended dose of nitrogen alone, in the two seasons of study. The same 
trends was found under the parts levels of nitrogen recommended dose of chemical fertilizer. The applications $3 / 4$ meniral nitrogen frtilizer plus humic and falvic acids had the highest values fresh root weight at 50 days from planting compared with recommended dose mineral nitrogen fertilizer, while, the application of $3 / 4 \mathrm{RD}(\mathrm{N})$ plus FYM, microbien or humic and fulvic acids had the highest fresh root weight at 70 days from planting, in both seasons. These findings may be attributed to the efected of organic and biofertilizers for giving a good source of plant nutrients and their role in improving soil physical structure and stimulate plant growth by producing growth regulates. These results are in line with those found by Shen and Shen (2001), Abraham and Lal (2003) and Khalilzedh et al., (2012).

Table (4): Effect of nitrogen fertilizers, organic (FYM), biofertilizer (Microbien) and humic and fulvic acids on root weight at $\mathbf{5 0}$ days and 70 days and leaf area of common bean in 2013 and 2014 seasons.

\begin{tabular}{|c|c|c|c|c|c|c|}
\hline \multirow[t]{2}{*}{ Treatments } & \multicolumn{2}{|c|}{$\begin{array}{c}\text { Fresh root } \\
\text { weight (g) at } 50 \\
\text { days }\end{array}$} & \multicolumn{2}{|c|}{$\begin{array}{c}\text { Fresh root } \\
\text { weight }(\mathrm{g}) \text { at } 70 \\
\text { days }\end{array}$} & \multicolumn{2}{|c|}{ Leaf area $\left(\mathrm{dm}^{2}\right)$} \\
\hline & $\begin{array}{c}2013 \\
\text { season }\end{array}$ & $\begin{array}{c}2014 \\
\text { season }\end{array}$ & $\begin{array}{c}2013 \\
\text { season }\end{array}$ & $\begin{array}{c}2014 \\
\text { season }\end{array}$ & $\begin{array}{c}2013 \\
\text { season }\end{array}$ & $\begin{array}{c}2014 \\
\text { season }\end{array}$ \\
\hline Control (untreated) & $0.827 \mathrm{~g}$ & $0.870 \mathrm{~h}$ & $1.257 \mathrm{~g}$ & $1.270 \mathrm{e}$ & $1.620 \mathrm{e}$ & $1.603 \mathrm{E}$ \\
\hline N Recommended Dose (RD) & $1.403 \mathrm{bcd}$ & & $2.527 \mathrm{e}$ & & $2.513 \mathrm{bcd}$ & $2.577 a b c$ \\
\hline & \begin{tabular}{|l|}
$1.477 b$ \\
\end{tabular} & & 2.623 & & & $0 \mathrm{ab}$ \\
\hline $\mathrm{RD}$ & $1.477 \mathrm{~b}$ & & $2.600 \mathrm{de}$ & $50 \mathrm{bc}$ & $3 \mathrm{bc}$ & $2.613 \mathrm{abc}$ \\
\hline \&Fulvic) & $1.743 a$ & & $2.887 a$ & $3 a$ & & $2.887 a$ \\
\hline ed Dose (RD) & $1.170 f$ & $1.287 f$ & $2.717 \mathrm{bcd}$ & $2.753 \mathrm{bc}$ & $2.373 \mathrm{~cd}$ & $2.360 \mathrm{bcd}$ \\
\hline $3 / 4 R D(N)+(F Y M)$ & $1.363 \mathrm{cde}$ & 1.403de & $2.733 \mathrm{bc}$ & $2.740 \mathrm{bc}$ & $2.540 \mathrm{bc}$ & $2.573 \mathrm{abc}$ \\
\hline 3/4 RD (N) + (Microbien) & $1.290 \mathrm{e}$ & $1.323 \mathrm{ef}$ & $2.787 \mathrm{ab}$ & $2.790 \mathrm{ab}$ & $2.437 \mathrm{bcd}$ & $2.517 a-d$ \\
\hline 3/4 RD (N) + (Humic\&Fulvic) & $1.443 \mathrm{bc}$ & $1.467 \mathrm{bcd}$ & $2.640 \mathrm{cde}$ & $2.707 \mathrm{bc}$ & $2.547 \mathrm{bc}$ & $2.590 \mathrm{abc}$ \\
\hline $1 / 2 \mathrm{NRe}$ & $1.147 \mathrm{f}$ & & $2.270 f$ & & & 83d \\
\hline $1 / 2 \mathrm{RL}$ & 1.323de & 1.393def & $2.610 \mathrm{cde}$ & & $2.340 \mathrm{~cd}$ & $2.327 \mathrm{bcd}$ \\
\hline $1 / 2 \mathrm{RL}$ & $1.140 f$ & & $2.273 f$ & $2.260 d$ & $3 \mathrm{~cd}$ & $2.253 \mathrm{~cd}$ \\
\hline $1 / 2$ RD (N) + (Humic\&Fulvic) & $1.313 \mathrm{de}$ & $1.377 \mathrm{def}$ & $2.630 \mathrm{cde}$ & $2.657 \mathrm{bc}$ & $2.433 \mathrm{bcd}$ & $2.383 \mathrm{bcd}$ \\
\hline
\end{tabular}

Mean values among variants were compared by using different litters according to Duncan's multiple range test.

\section{Leaf area :}

Results dealing with the effect of farm yard manure, microbien and humic and fulvic acids on leaf area $\left(\mathrm{dm}^{2}\right)$ under the level of the recommended dose and levels of its parts are show in Table (4), results reveal that all studied combination significantly increased leaf area as compared to untreated one, in the two seasons under study. The highest values of this trait i.e., $\left(2.917\right.$ and $\left.2.887 \mathrm{dm}^{2}\right)$ were obtained by the combination between the recommended dose of chemical nitrogen with humic and fulvic acids. Also, this trend was found in the two seasons. Applying FYM, microbien or humic and fulvic acids at the rate of $1 / 2$ the recommended dose of nitrogen fertilizer obtained values of leaf area $\left(\mathrm{dm}^{2}\right)$ less than those of similar treatment at the recommended dose of nitrogen fertilizer. While, the application of $3 / 4 \mathrm{RD}(\mathrm{N})$ plus FYM, microbien or humic and fulvic acids observed that values leaf area $\left(\mathrm{dm}^{2}\right)$ were the higher than with application the recommended dose mineral 
nitrogen fertilizer. The obtained data clear that the effects of applying FYM and humic and fulvic acids with the level of $3 / 4$ nitrogen recommended dose on leaf area $\left(\mathrm{dm}^{2}\right)$ were equal to those obtained by the recommended dsoe of nitrogen fertilizer alone during the two seasons under study. Khalizadeh et al., (2012) come to the same trend.

\section{Nitrogen contents in the leaves and fresh pods :}

Results in Table (5) clearly indicate that organic, biofertilizer and humic and fulvic acids and their interactions with nitrogen recommended dose or its parts significantly increased nitrogen contents percentage in both leaves and fresh pods as compared to untreated one, in the two seasons of study. The highest values of nitrogen contents (\%) in leaves were produced in 2013 season by applying nitrogen recommended dose plus farm yard manure (3.357\%), while, the highest values of nitrogen contents (\%) in leaves at 2014 season was obtained by applying the recommended dose of nitrogen plus himic and fulvic acids (3.417\%).

Table (5): Effect of nitrogen fertilizers, organic (FYM), biofertilizer (Microbien) and humic and fulvic acids on leave and fresh pods $\mathrm{N}$-contents and number of pods/plant of common bean in 2013 and 2014 seasons.

\begin{tabular}{|c|c|c|c|c|c|c|}
\hline \multirow{2}{*}{ Treatments } & \multicolumn{2}{|c|}{$\begin{array}{l}\text { Leaves } \mathrm{N}- \\
\text { contents \% }\end{array}$} & \multicolumn{2}{|c|}{$\begin{array}{c}\text { Fresh pods N- } \\
\text { contents } \%\end{array}$} & \multicolumn{2}{|c|}{$\begin{array}{c}\text { No. of } \\
\text { pods/plant }\end{array}$} \\
\hline & $\begin{array}{c}2013 \\
\text { season }\end{array}$ & \begin{tabular}{|c|}
2014 \\
season
\end{tabular} & $\begin{array}{c}2013 \\
\text { season }\end{array}$ & \begin{tabular}{|c|}
2014 \\
season
\end{tabular} & $\begin{array}{c}2013 \\
\text { season }\end{array}$ & $\begin{array}{c}2014 \\
\text { season }\end{array}$ \\
\hline Control (untreated) & $2.110 \mathrm{e}$ & $2.117 \mathrm{~h}$ & $2.110 \mathrm{e}$ & $2.117 \mathrm{~h}$ & $9.57 \mathrm{j}$ & $9.73 \mathrm{~h}$ \\
\hline N Recommended Dose (RD) & $3.327 a$ & $3.303 a$ & $3.327 a$ & $3.303 a$ & $26.28 \mathrm{c}$ & $26.03 c$ \\
\hline$R D(N)+(F Y M)$ & $3.357 a$ & $3.373 a$ & $3.357 a$ & $3.373 a$ & $28.35 a$ & $28.56 a$ \\
\hline$)+($ Microbien $)$ & $3.260 \mathrm{a}$ & $3.307 a$ & $3.260 a$ & $3.307 a$ & $27.03 b$ & $27.35 b$ \\
\hline RD (N) + (Humic\&Fulvic) & $3.320 a$ & $3.417 a$ & $3.320 a$ & $3.417 a$ & $28.79 a$ & $29.05 a$ \\
\hline $3 / 4 \mathrm{NR}$ & $2.807 b$ & $2.740 \mathrm{~cd}$ & $2.807 b$ & $2.740 \mathrm{~cd}$ & $19.82 \mathrm{~h}$ & $20.08 f$ \\
\hline $3 / 4 R D(N)+(F Y M)$ & $2.958 b$ & $2.920 \mathrm{~b}$ & $2.958 b$ & $2.920 \mathrm{~b}$ & $26.23 c$ & $25.91 c$ \\
\hline 3/4 RD (N) + (Microbien) & $2.610 \mathrm{c}$ & 2.590de & $2.610 \mathrm{c}$ & 2.590de & $25.36 d$ & $25.46 c$ \\
\hline 3/4 RD (N) + (Humic\&Fulvic) & $2.943 b$ & $2.860 \mathrm{bc}$ & $2.943 b$ & $2.860 \mathrm{bc}$ & $26.14 c$ & $26.20 \mathrm{c}$ \\
\hline $1 / 2$ N Recommended Dose (RD) & $2.417 d$ & 2.227gh & $2.417 d$ & $2.227 \mathrm{gh}$ & $16.70 \mathrm{i}$ & $16.89 \mathrm{~g}$ \\
\hline $1 / 2 \mathrm{RD}(\mathrm{N})+(\mathrm{FYM})$ & $2.487 \mathrm{~cd}$ & $2.387 \mathrm{fg}$ & $2.487 \mathrm{~cd}$ & $2.387 \mathrm{fg}$ & $23.65 e$ & 23.81d \\
\hline $1 / 2 \mathrm{RD}(\mathrm{N})+($ Microbien) & $2.460 \mathrm{~cd}$ & $2.350 \mathrm{fg}$ & $2.460 \mathrm{~cd}$ & $2.350 \mathrm{fg}$ & $21.30 \mathrm{~g}$ & $21.51 \mathrm{e}$ \\
\hline $1 / 2 \mathrm{RD}(\mathrm{N})+$ (Humic\&Fulvic) & $2.537 \mathrm{~cd}$ & 2.460ef & $2.537 \mathrm{~cd}$ & 2.460ef & $22.15 f$ & $22.31 \mathrm{e}$ \\
\hline
\end{tabular}

Mean values among variants were compared by using different litters according to Duncan's multiple range test.

The effect of adding farm yard manure was clearly shown at $3 / 4$ the recommended dose of nitrogen fertilizer and all the recommended dose of nitrogen fertilizer, while, the effct of adding himic and fulvic acids was noteced at the level of $1 / 2$ nitrogen recommended dose. Mocrobien gave the lowest values of nitrogen in leaves (\%) at any of the recommended dose of nitrogen fertilizer and its parts. The highest values of fresh pods nitrogen contents were recorded by nitrogen recommended dose and its parts with adding humic and fulvic acids during the two seasons of study. These results could 
be due to the role of the organic and biofertilizers in increasing the permeability of plant membranes and enhancing the uptake of nutrients especially nitrogen (Singer et al., 1998 and Pascual et al., 1999). Humic and fulvic acids are considered to be compounds increasing permeability of cellular membranes in plants (Kaya et al., 2005).

\section{Number of pods per plant:}

Data shown in Table (5) clearly reveal that all studied treatments gave number of pods/plant values significantly surpassed that produced by the untreated one, in the two seasons of study. Applying humic and fulvic acids with the level of recommended dose of nitrogen obtained the highest values of number of pods/plant, the same trend was found by applying humic and fulvic acids with $1 / 2$ the recommended dose of nitrogen fertilizer produced the higher values as compared to the values of number of pods/plant obtained by farm yard manure and microbien at the same level. Farm yard manure obtained the higher values of number of pods/plant as compared of those obtained by microbien and humic and fulvic acids at the level adding $3 / 4$ of nitrogen recommended dose under the two seasons under study. No significant effect between $3 / 4 \mathrm{RD}(\mathrm{N})+\mathrm{FYM}, 3 / 4 \mathrm{RD}(\mathrm{N})$ + Microbien and $3 / 4 \mathrm{RD}$ (N) + humic and fulvic acids compared with the recommended dose of chemical nitrogen of number of pods/plant. The increments induced in number of pods/plant may be attributed to the many benefits of humic and fulvic acids and enhancing uptake of several essential nutrients. Kaya et al., (2005) reported that using humic and fulvic acids are considered to be compounds increasing permeability of cellular membranes in plants to vitamins within the cells.

\section{Fresh pods yield :}

Results listed in Table (6) revealed that increased fertilizing common bean plant with recommended dose of nitrogen or with its parts combining with farm yard manure, microbein and humic and fulvic acids significantly fresh pods weight (ton/fed) more than those obtained by the untreated treatment. These were true in both seasons of study. These results are in agreement with those reported by Abraham and Lal (2003). The highest values of fresh pods weight were recorded with applying farm yard manure plus the recommended dose of nitrogen fertilizer ( 3.985 and 3.961 ton/fed) in the first and second seasons, respectively. No significant effect were found between 3/4 RD (N) + FYM, 3/4 RD (N) + Microbien and 3/4 RD (N) + humic and fulvic acids treatment and the recommended dose of chemical nitrogen in fresh pods yield.

Applying farm yard manure, microbien or humic and fulvic acids plus the recommended dose of nitrogen fertilizer, $3 / 4$ the recommended dose of nitrogen fertilizer or $1 / 2$ the recommended dose of nitrogen fertilizer obtained the higher values of fresh pods weight in comparison with those obtained by the single levels of nitrogen. Farm yard manure produced the highest pods yield as compared to either the recommended dose of nitrogen fertilizer or $1 / 2$ the recommended dose of nitrogen fertilizer, while, treating common bean with humic and fulvic acids plus $3 / 4$ the recommended dose of nitrogen fertilizer had the highest values of fresh pods yield as compared to the other treatments at the same level during the two seasons of study (2013 and 
2014). The results clear that the application of $3 / 4$ the recommended dose of mineral nitrogen fertilizer plus FYM, microbien or humic and fulvic acids produced the highest values of fresh pods yield compared with those obtained by the application of the recommended dose of mineral nitrogen fertilizer. These results are in agreement with those reported by Abraham and Lal (2003). Whereas, the farm yard manure may be improve physical and chemical soil properties and nutrient content soil that may be reflect positively on the growth and yield.

Table (6): Effect of nitrogen fertilizers, organic (FYM), biofertilizer (Microbien) and humic and fulvic acids on fresh pods yield and exportable fresh pods yield of common bean in 2013 and 2014 seasons.

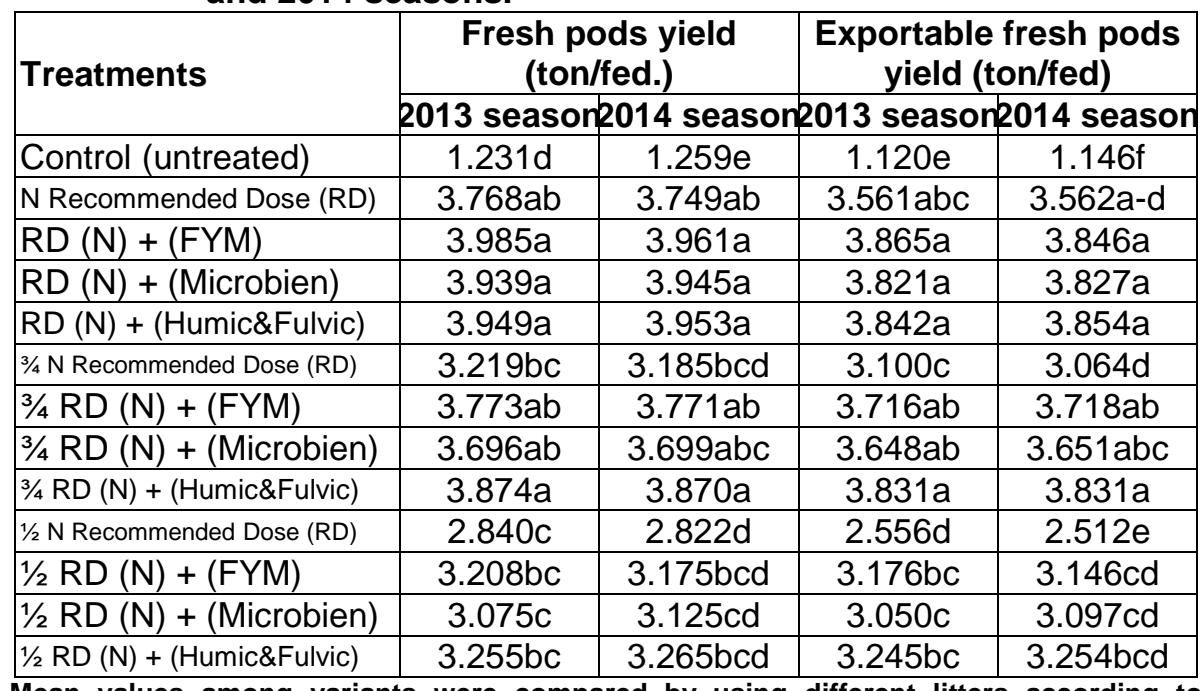

Mean values among variants were compared by using different litters according to Duncan's multiple range test.

\section{Exportable fresh pods yield :}

Data in Table (6) clearly show that the highest values of exportable fresh pods yield were recorded with applying farm yard manure plus the recommended dose of nitrogen fertilizer (3.865 and 3.846 ton/fed) in the first and second seasons, respectively. No significant differences among the treatments of applying farm yard manure, microbien or humic and fulvic acids plus $3 / 4$ the recommended dose of nitrogen fertilizer with the recommended dose of nitrogen fertilizer.

These results indicated that common been can be fertilizing by $3 / 4$ the recommended dose of nitrogen fertilizer plus farm yard manure, microbien or humic and fulvic acids to improve the produce of common bean and also decrease the mineral hazard. These results are in agreement with those reported by Abraham and Lal (2003). 


\section{REFERENCES}

A.O.A.C. (1984). Official Methods of Analysis, $12^{\text {th }}$ ed. "Association of Official Analytical Chemists". Washington, D.C.

Abraham, T. and R.B. Lal (2003). Strategies for INM technology in sustainable edapho-cultivar management for a legume based (soybean-mustard-fodder cowpea) cropping system for the inceptisols in the NEPZ. Crop Research Hisar., 26 (1): 33-41.

Araújo, A.S.F., R.T.R. Monteiro and E.M.S. Carvalho (2007). Effect of composted textile sludge on growth, nodulation and nitrogen fixation of soybean and cowpea. Bioresource Technology. 98 (5):1028-1032.

De Silva, S.H.S.A. and H.F. Cook (2003). Soil physical conditions and performance of cowpea following organic matter amelioration of sand. Commun. Soil Sci. Plant Anal., 34 (7/8): 1039- 1058.

Duncan D.B. (1955). Multiple range and multiple $F$ tests. Biometrics, 11: 1-45.

El-Akabawy, M.A. (2000). Effect of biofertilizers and farm yard manure on yield and nutrient uptake of Egyptian clover on loamy sand soil. Egypt. J. Agric. Res. 78 (5): 1811-1820.

Gomez, K.A. and A.A. Gomez (1984) Statistical Procedures for Agricultural Research. John Willy and Sons. New York, pp. 680.

Jackson, M.L. (1967). Soil Chemical analysis. Prentice-Hall, Inc., Englewood Cliffs, New Jersey, USA.

Kaya M., M. Atak, K.M. Khawar, C.Y. Ciftci and S. Ozcan (2005). Effect of pre-sowing seed treatment with zink and foliar spray humic acids on field of common bean (Phaseolus vulgaris L.). J. Agric.Biol.,7: 875-878.

Khalilzadeh, R., M. Tajbakhsh and J. Jalilian (2012). Growth characteristics of mung bean (Vigna radiata L.) affected by foliar application of urea and bio-organic fertilizers. International J.Agric. and Crop Sci.,IJACS637642.

Mel'nikova, N.N., L.V. Bulavenko, I.K. Kurdish, L.V. Titova and S.Ya. Kots (2002). Formation and Function of the Legume-Rhizobium Symbiosis of Soybean Plants while Introducing Bacterial Strains from the Genera Azotobacter and Bacillus. Applied Biochemistry and Microbiology. 38 (4): $368-372$.

Pascual, J.A., C. Garcia and T, Hernandez (1999). Comparison of fresh and composted organic waste in their efficacy for the improvement of arid soil quality. Bioresources Technol., 68: 255-264.

Piccolo, A., G. Pietramellara and J.S.C. Mbagwu (1997). Reduction in soil loss from erosion-susceptible soils amended with humic substances from oxidized coal. Soil Technol., 10: 235-245.

Shen, Q.R. and Z.G. Shen (2001). Effects of pig manure and wheat straw on growth of mung bean seedlings grown in aluminum toxicity soil. Bioresource Technology, 76, 235-240.

Singer, S.M., O.M. Sawan, M.M. AbdelMouty and S.R. Salman (1998). Study of the effects of the Delta mixTM and organic matter on growth and productivity of bean plants grown under calcareous soil conditions. Egyptian J. Hort., 25: 335-247. 
Wu, S.C.; Z.H. Cao, Z.G. Li, K.C. Cheung and M.H. Wong (2005). Effect of biofertilizer containing $\mathrm{N}$ - fixer, $\mathrm{P}$ and $\mathrm{K}$ solubilizer and $\mathrm{AM}$ fungi on maize growth: a green house trail. Geoderma 125 (1-2): 155-166.

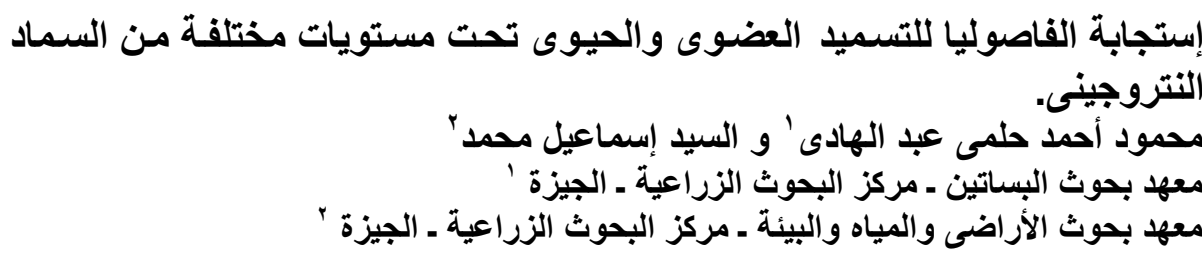

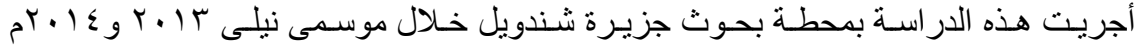

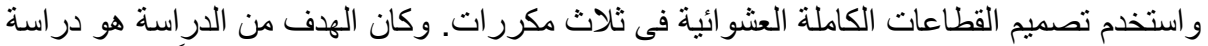

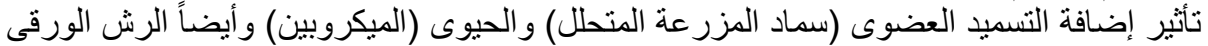

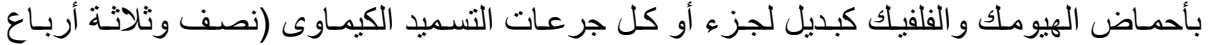

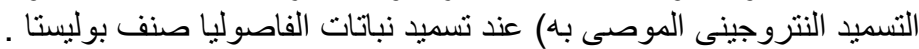
وكانت أهم النتائج كالتالى :

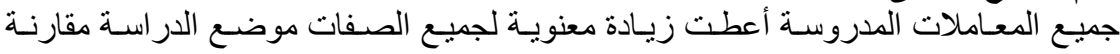

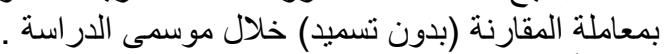

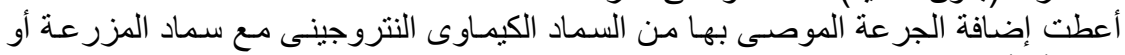

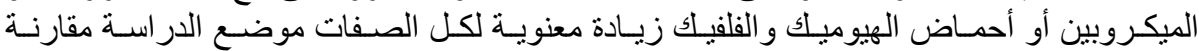

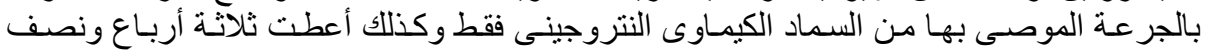

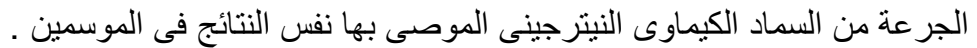

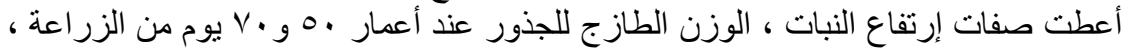

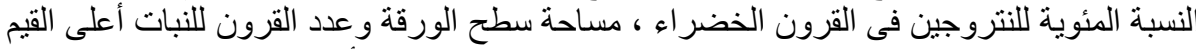

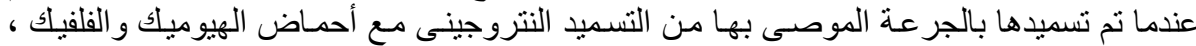

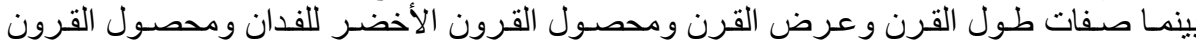

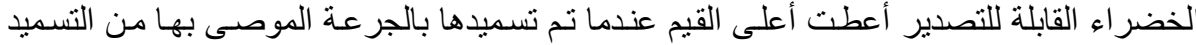

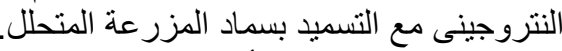

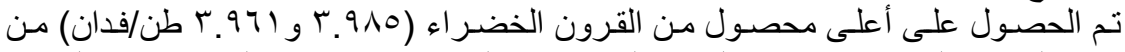

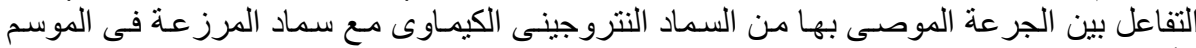

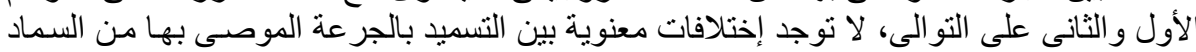

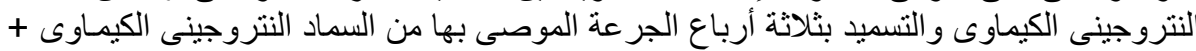

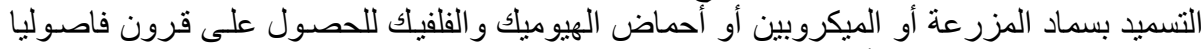

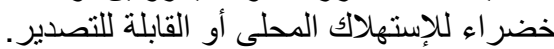

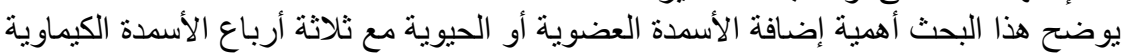
من أجل تحسين المحصول الناتج وخفض إضكاليف السماد المعدنى وكذلك التلوث البيئى . 